\title{
Oxidative stress inhibits the phagocytosis of apoptotic cells that have externalized phosphatidylserine
}

\author{
HA Anderson ${ }^{*, 1}$, R Englert ${ }^{1,3}$, I Gursel $^{2}$ and E Shacter ${ }^{1}$ \\ ${ }^{1}$ Laboratory of Immunology, Division of Therapeutic Proteins, Bethesda, MD \\ 20892, USA \\ 2 Laboratory of Retroviral Research, Division of Viral Products, FDA/CBER, \\ Bethesda, MD 20892, USA \\ 3 US Navy, Uniformed Services University of the Health Sciences, Bethesda, MD \\ 20879, USA \\ * Corresponding author: $\mathrm{H}$ Anderson, Laboratory of Immunology, Division of \\ Therapeutic Proteins, FDA/CBER, Bld 29A, Rm 2A-07, Bethesda, MD 20892, \\ USA. Tel: 301-594-6679; Fax: 301-480-3256; \\ E-mail: andersonh@cber.fda.gov
}

Received 9.11.01; revised 14.12.01; accepted 17.12.01

Edited by T Ferguson

\begin{abstract}
The efficient phagocytosis of apoptotic cells by macrophages reduces the potential for an inflammatory response by ensuring that the dying cells are cleared before their intracellular contents are released. Early apoptotic cells are targeted for phagocytosis through the translocation of phosphatidylserine (PS) from the inner to the outer leaflet of the plasma membrane. In this report, we show that the oxidant $\mathrm{H}_{2} \mathrm{O}_{2}$ inhibits phagocytosis of apoptotic cells even though the cells express functional PS on their surface. Thus, B lymphoma cells induced to undergo apoptosis by the chemotherapy drug etoposide are efficiently phagocytosed by macrophages in a process that is mediated by PS (inhibitable by PS liposomes). Exposure of the apoptotic cells to $\mathrm{H}_{2} \mathrm{O}_{2}$ inhibits phagocytosis even though the cells still express functional PS on their surface. In addition, Jurkat cells and thymocytes induced to undergo apoptosis by $\mathrm{H}_{2} \mathrm{O}_{2}$ alone are poorly phagocytosed. Inhibition of phagocytosis by $\mathrm{H}_{2} \mathrm{O}_{2}$ cannot be attributed to oxidative inactivation or redistribution of PS on the cell surface. The results indicate that PS externalization is necessary but is not sufficient to target apoptotic cells for phagocytosis. Another phagocytosis recognition factor must therefore exist to facilitate uptake of apoptotic cells, and this factor is sensitive to modification by $\mathrm{H}_{2} \mathrm{O}_{2}$.

Cell Death and Differentiation (2002) 9, 616-625. DOI: 10.1038/ sj/cdd/4401013
\end{abstract}

Keywords: apoptosis; phagocytosis; phosphatidylserine; oxidants

Abbreviations: PS, phosphatidylserine; $\mathrm{BL}$, Burkitt's lymphoma; $\mathrm{H}_{2} \mathrm{O}_{2}$, hydrogen peroxide; PARP poly-ADP ribose polymerase; 3-AB, 3-aminobenzamide; VP16, etoposide; PG, phosphatidylglycerol

\section{Introduction}

Apoptotic death is a conserved cellular process that functions to target cells for phagocytosis by macrophages. This physiological event is of fundamental importance because it ensures that cells are removed before plasma membrane integrity is lost and cytosolic molecules are released into the extracellular milieu (for review see ${ }^{1}$ ). Leakage of intracellular molecules is thought to cause the induction of potentially harmful inflammatory responses., ${ }^{2,3}$ Indeed, some autoimmune diseases may have etiologies associated with impaired uptake of apoptotic cells. ${ }^{4-6}$

A number of molecules have been identified as being involved in the timely phagocytosis of apoptotic cells by macrophages. On the surface of the macrophage, CD14, ${ }^{7}$ CD91, ${ }^{8}$ scavenger receptors, ${ }^{9,10}$ and a receptor specific for phosphatidylserine (PS), ${ }^{11}$ have been implicated as important mediators of macrophage recognition of apoptotic cells. Integrins on the surface of macrophages appear to promote adhesion, ${ }^{12-14}$ and generate signals ${ }^{15}$ necessary for the phagocytosis of apoptotic cells. In addition, members of the complement system, ${ }^{16-18}$ thrombospondin, ${ }^{19}$ and protein $\beta 2$ glycoprotein $\mathrm{I}^{20}$ in serum have been demonstrated to bind apoptotic cells and facilitate their removal.

The only phagocytosis-associated change known to occur on the apoptotic cell surface is the translocation of PS from the inner leaflet to the outer leaflet of the plasma membrane. ${ }^{21,22}$ This event often requires caspase activation and is observed early during apoptosis. ${ }^{23}$ Substantial evidence indicates that PS is a key recognition moiety that targets many types of apoptotic cells for phagocytosis (for review $s^{24}$ ). Recently, Fadok and colleagues demonstrated that the introduction of PS into the external leaflet of the plasma membrane of healthy cells can target cells for phagocytosis by macrophages. ${ }^{25}$ This finding suggests that PS expression on the surface of cells is sufficient for ensuring their removal by macrophages. However, this finding does not preclude the possibility that other elements on the apoptotic cell surface may also promote phagocytosis.

The complex morphological changes associated with apoptosis require the energy provided by ATP hydrolysis. ${ }^{26,27}$ Oxidative stress induced by $\mathrm{H}_{2} \mathrm{O}_{2}$ causes extensive DNA damage and the activation of poly-ADP ribose polymerase (PARP), ${ }^{28}$ which leads to a rapid depletion of cellular ATP. ${ }^{29}$ Oxidative damage can therefore inhibit apoptotic processes and convert cell death to necrosis. ${ }^{27}$ From a physiologic perspective this is important since phagocytosis of necrotic cells is not initiated until after membrane integrity is lost. ${ }^{30}$

The present study was initiated to determine if the externalization of PS on the surface of $\mathrm{H}_{2} \mathrm{O}_{2}$-treated cells correlated with the ability of the cells to be phagocytosed 
by macrophages. Interestingly, when ATP levels in $\mathrm{H}_{2} \mathrm{O}_{2}$ treated $\mathrm{BL}$ cells are maintained through the inhibition of PARP, the cells undergo extensive apoptosis and PS is externalized to the plasma membrane surface. However, phagocytosis of these cells is very inefficient. In addition, Jurkat $\mathrm{T}$ cells and thymocytes treated with low doses of $\mathrm{H}_{2} \mathrm{O}_{2}$ become apoptotic and externalize PS, but these cells are also inefficiently phagocytosed. Thus, PS externalization does not guarantee efficient phagocytosis of apoptotic cells, and the removal of these cells requires a factor that is sensitive to $\mathrm{H}_{2} \mathrm{O}_{2}$ treatment.

\section{Results}

\section{$\mathrm{H}_{2} \mathrm{O}_{2}$ treatment of cells prevents etoposide- induced apoptosis and PS externalization}

Some BL cells fail to die by apoptosis when treated with the chemotherapeutic drug etoposide (VP16) in the presence of $\mathrm{H}_{2} \mathrm{O}_{2}{ }^{27}$ Instead, cell death is delayed, occurs by pyknosis necrosis, and cells are not phagocytosed until membrane integrity is lost. ${ }^{30}$ Because of the known role of PS in mediating phagocytosis of apoptotic cells, we evaluated the effect of $\mathrm{H}_{2} \mathrm{O}_{2}$ on the ability of BL cells to externalize PS. As shown in Figure 1, BL cells were induced to externalize PS when treated with etoposide. However, if cells were treated with etoposide in the presence of $200 \mu \mathrm{M} \mathrm{H}_{2} \mathrm{O}_{2}$, these cells failed to externalize PS. When 3-aminobenzamide (3-AB), a poly-ADP ribose polymerase inhibitor, was added to the treatment mixture, PS externalization was detected on the surface of cells treated with etoposide and $\mathrm{H}_{2} \mathrm{O}_{2}$ and was comparable to that observed with etoposide treatment alone. Annexin $\mathrm{V}$ positive $\mathrm{BL}$ cells as shown in Figure $1 \mathrm{~A}$ were impermeable to propidium iodide, indicating that they maintained their membrane integrity. BL cells treated with $\mathrm{H}_{2} \mathrm{O}_{2}$ and 3-AB demonstrated two populations of annexin $V$ positive cells when examined at $7 \mathrm{~h}$. At $9 \mathrm{~h}$ these cells demonstrated a single population of annexin $\mathrm{V}$ positive cells, identical to cells treated with etoposide (data not shown). This suggests that $\mathrm{BL}$ cells undergo apoptosis with slower kinetics when treated with $\mathrm{H}_{2} \mathrm{O}_{2}$ and 3-AB. Examination
A

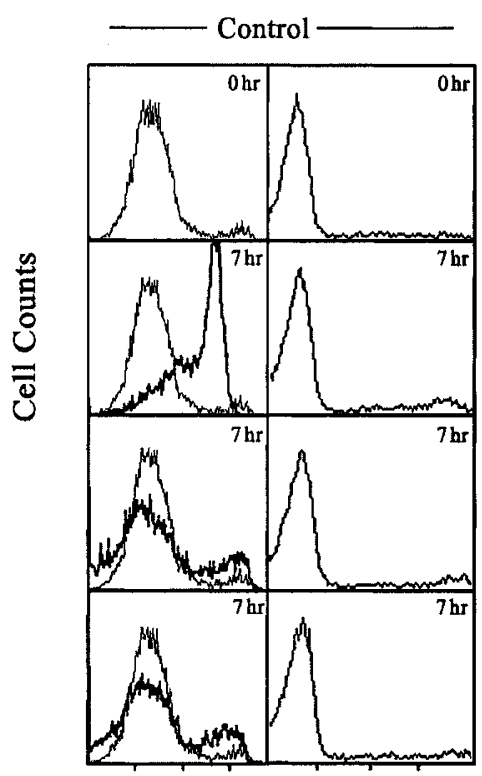

Annexin V-FITC Propidium lodide

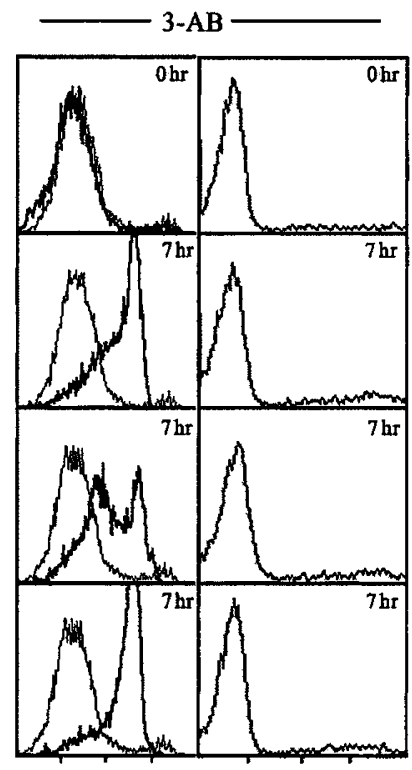

Annexin V-FITC Propidium Iodide
B

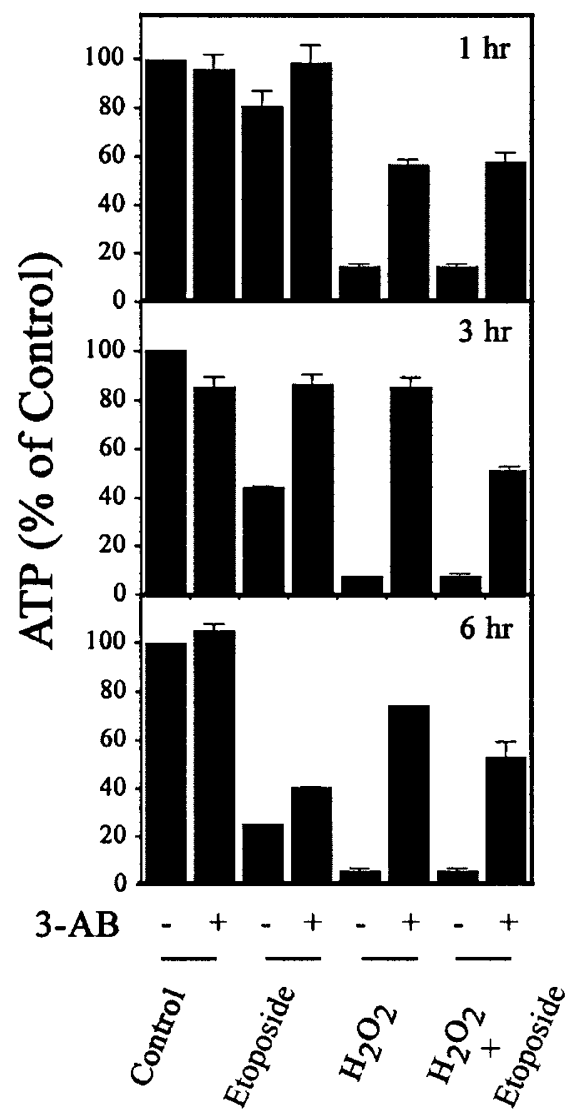

Figure 1 Effect of $3-A B$ on PS-externalization and ATP levels in cells treated with $\mathrm{H}_{2} \mathrm{O}_{2}$ and etoposide. (A) BL cells were treated with $200 \mu \mathrm{g} / \mathrm{ml}$ etoposide and/or $200 \mu \mathrm{M} \mathrm{H}_{2} \mathrm{O}_{2}$ for $7 \mathrm{~h}$ in the absence or presence of $1 \mathrm{mM} \mathrm{3-AB}$. Cells were then stained with annexin V-FITC and monitored by FACScan analysis to assay for the extent of PS surface expression, or treated with propidium iodide to assay for membrane integrity. Data are shown on a log scale, and annexin $V$ binding to control cells is shown in each FACscan profile (light line). Heavy lines show treated cells. (B) Identical cultures were assayed for ATP content at the indicated times as described in the Materials and Method section. Results are expressed as the percentage of ATP measured in treated cultures compared to the ATP content in control cultures. Error bars denote the standard deviation 
of nuclear morphology as described previously ${ }^{27,30}$ confirmed that the cells expressing PS had nuclear condensation characteristic of apoptosis and that the cells were impermeable to propidium iodide (data not shown). Thus, BL cells can undergo extensive apoptosis and externalize PS in the presence of $\mathrm{H}_{2} \mathrm{O}_{2}$ if PARP is inhibited. ${ }^{27,30,31}$

Previous studies suggested that $\mathrm{H}_{2} \mathrm{O}_{2}$-induced apoptosis in the presence of $3-A B$ can be attributed to the ability of these cells to maintain adequate levels of ATP to sustain apoptosis. ${ }^{27}$ This was confirmed by measuring ATP levels in cells treated with etoposide and/or $\mathrm{H}_{2} \mathrm{O}_{2}$. As shown in Figure $1 \mathrm{~B}$, within $1 \mathrm{~h}$ after exposure to $\mathrm{H}_{2} \mathrm{O}_{2}$, cellular ATP levels were reduced by $90 \%$ compared to control cells, while etoposide treated cells maintained ATP at levels similar to untreated cells. Cells treated with $\mathrm{H}_{2} \mathrm{O}_{2}$ in the presence of $3-A B$ maintained ATP levels of at least $50 \%$ of the levels in untreated cells. These findings are consistent with reports that ATP levels must be maintained to at least $25 \%$ of normal levels for the initiation of apoptosis. ${ }^{26}$ Thus, together with the data in Figure 1, these results support the conclusion that ATP is required for the externalization of PS (and the induction of apoptosis), ${ }^{23,32}$ and that $\mathrm{H}_{2} \mathrm{O}_{2}$ prevents $\mathrm{BL}$ cell apoptosis indirectly by depleting cellular ATP. ${ }^{27}$ Note that cells treated with etoposide undergo extensive apoptosis within $3 \mathrm{~h}$ such that the low levels of ATP seen in $6 \mathrm{~h}$ etoposide-treated cells are those seen near the end of the apoptotic process.

\section{$\mathrm{H}_{2} \mathrm{O}_{2}$ treatment prevents phagocytosis of apoptotic cells that have translocated PS}

The translocation of PS to the outer leaflet of the plasma membrane has been demonstrated to be an essential event that targets cells for phagocytosis. ${ }^{24}$ In order to determine if PS mediates phagocytosis in our experimental system, we evaluated the ability of human macrophages to phagocytose $\mathrm{BL}$ cells treated with etoposide and/or $\mathrm{H}_{2} \mathrm{O}_{2}$, and correlated this with PS expression. BL cells were incubated with human monocyte-derived macrophages for $1 \mathrm{~h}$ at $37^{\circ} \mathrm{C}$ to allow for phagocytosis of the cells. Phagocytosis of apoptotic BL cells was quantified by FACscan analysis and is expressed as the fold-increase in phagocytosis. This value was determined by calculating the relative increase in the percentage of macrophages that engulfed treated-BL cells compared to the percentage of macrophages that engulfed untreated $\mathrm{BL}$ cells (control). This evaluation allowed for a better comparison between experiments since macrophages derived from different human donors demonstrated differences in overall levels of phagocytosis. It should be noted that identical results were obtained when phagocytosis was quantified with fluorescence microscopy as previously described, ${ }^{30}$ and that nearly all of the apoptotic cells were present inside macrophages. Less than $5 \%$ of the macrophages had apoptotic cells bound to the macrophage cell surface (data not shown). As shown in Figure 2, there was a fivefold increase in the phagocytosis of etoposide-treated (apoptotic) BL cells compared to the phagocytosis of healthy cells. However, BL cells treated with etoposide in the presence of $\mathrm{H}_{2} \mathrm{O}_{2}$ were poorly phagocytosed, as were cells treated with $\mathrm{H}_{2} \mathrm{O}_{2}$ alone. This
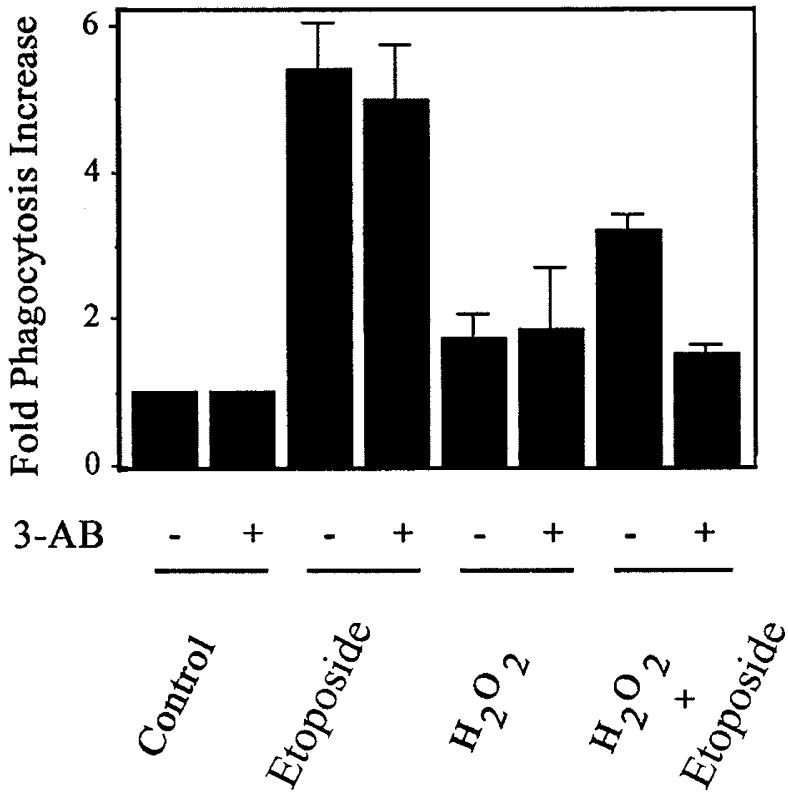

Figure $2 \mathrm{H}_{2} \mathrm{O}_{2}$ inhibits phagocytosis of apoptotic cells that have externalized PS. BL cells were treated with etoposide $(200 \mu \mathrm{g} / \mathrm{ml})$ and $/ \mathrm{or}_{2} \mathrm{O}_{2}(200 \mu \mathrm{M})$ and cultured in the absence or presence of $1 \mathrm{mM} 3-\mathrm{AB}$ for $7 \mathrm{~h}$ as described for Figure 1. BL cells were fluorescently labeled with the green fluorescent dye CFDA, washed and incubated with macrophages (stained with PE) derived from human peripheral blood monocytes for $1 \mathrm{~h}$ at $37^{\circ} \mathrm{C}$. Phagocytosis of $\mathrm{BL}$ cells is expressed as the fold increase in engulfment of treated BL cells compared to control BL cells. Error bars denote the standard deviation

was initially attributed to the inability of these cells to externalize PS to the cell surface (Figure 1A). Surprisingly, however, when $B L$ cells were treated with etoposide and/or $\mathrm{H}_{2} \mathrm{O}_{2}$ in the presence of $3-\mathrm{AB}$, these cells also were poorly phagocytosed by macrophages (Figure 2) even though they expressed similar amounts of PS as compared to cells treated with etoposide alone (see Figure 1). These results suggest that $\mathrm{BL}$ cells induced to undergo apoptosis in the presence of $\mathrm{H}_{2} \mathrm{O}_{2}$ can externalize $\mathrm{PS}$, but these cells are poorly phagocytosed by macrophages.

\section{PS exposure on the surface of apoptotic BL cells is required for phagocytosis}

The observation that PS expression on BL cells does not ensure phagocytosis of apoptotic cells necessitated a reevaluation of the role of PS in the phagocytosis of these cells. In initial studies, the kinetics of PS expression were compared with the kinetics of phagocytosis of apoptotic BL cells. As shown in Figure 3A, cells first began to express PS $2 \mathrm{~h}$ after etoposide treatment, and by $3.5 \mathrm{~h}$, approximately $50 \%$ of the population of cells had translocated PS to the outer plasma membrane surface. BL cell membrane integrity was maintained during this time period since cells remained impermeable to staining with propidium iodide (upper right quadrant). In the same experiments, etoposide treated BL cells were assayed to determine at which time the cells became susceptible to phagocytosis. As shown in Figure 3B, an increase in phagocytosis of BL cells was first observed $1.5 \mathrm{~h}$ after etoposide treatment, and increased at 
A

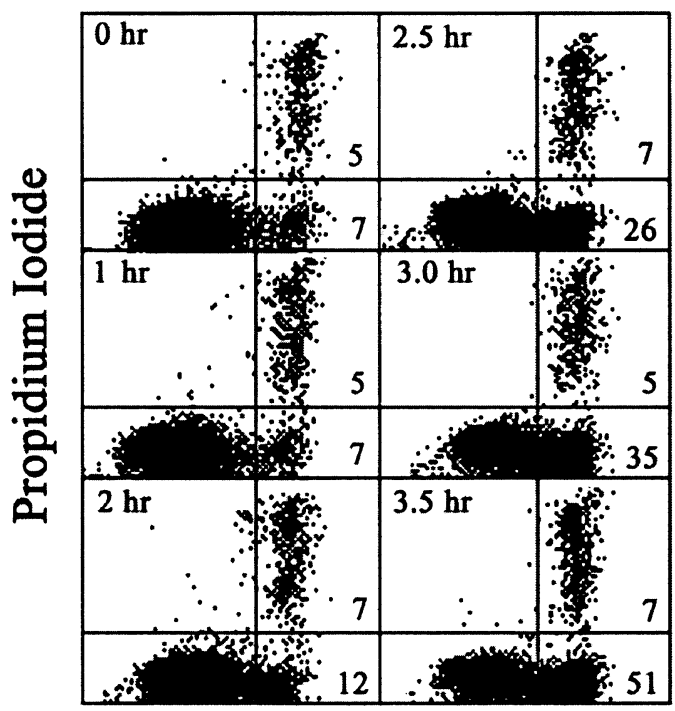

Annexin V-FITC

B
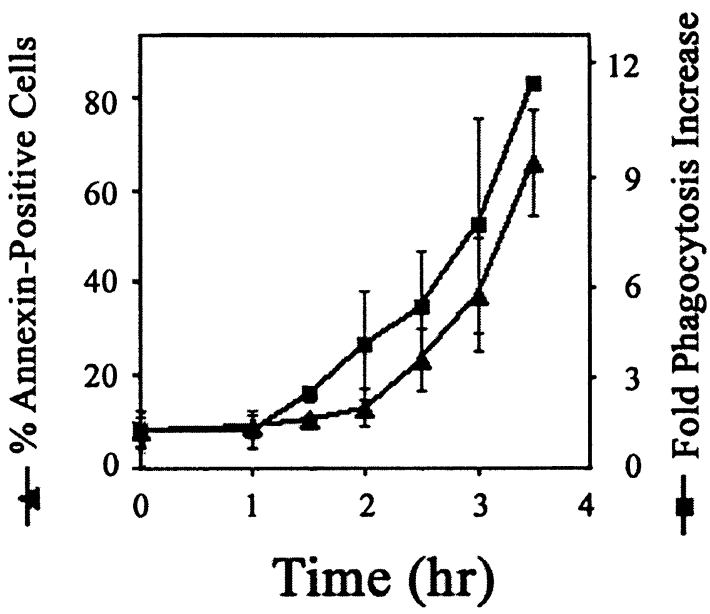

Figure 3 Kinetics of PS externalization and phagocytosis of etoposidetreated BL cells. (A) BL cells were treated with $200 \mu \mathrm{g} / \mathrm{ml}$ etoposide for the indicated periods of time. The kinetics of PS externalization were determined by two-color FACScan analysis after incubating cells with annexin V-FITC and $\mathrm{PI}$. Apoptotic cells with an intact plasma membrane appear in the lower right quadrant. Late apoptotic or necrotic cells that have lost plasma membrane integrity appear in the upper right quadrant. The percentage of cells present in each quadrant is indicated. (B) Human macrophages were incubated for $1 \mathrm{~h}$ with $B L$ cells treated with etoposide for various periods of time. Phagocytosis was measured as described in the Materials and Methods section. The kinetics of PS externalization is compared to fold increase in phagocytosis of VP16 treated $\mathrm{BL}$ cells. Error bars denote the standard deviation

a rate similar to PS externalization. Thus, the kinetics of PS exposure on $\mathrm{BL}$ cells are similar to the kinetics of recognition and phagocytosis of these cells by macrophages, with the possibility that the increase in phagocytosis slightly precedes the externalization of PS.
To further evaluate the role of PS in the phagocytosis of etoposide-induced apoptotic BL cells, the ability of PScontaining liposomes to inhibit phagocytosis was measured. BL cells were treated with etoposide for various periods of time and phagocytosis was assayed in the presence of various amounts of liposomes containing PS or phosphatidylglycerol (PG). As shown in Figure 4, PScontaining liposomes reduced phagocytosis of etoposidetreated $\mathrm{BL}$ cells in a concentration-dependent manner, achieving approximately $75 \%$ inhibition at the highest concentrations tested. PG-containing liposomes were approximately half as effective as PS-containing liposomes in inhibiting phagocytosis of etoposide-treated BL cells. The slight inhibition of phagocytosis observed with PG-containing liposomes may be attributed to nonspecific charge effects that reduce the interaction of apoptotic cells with macrophages. ${ }^{33}$ The inability to completely inhibit phagocytosis with PS containing liposomes has been found by

\section{- PG \\ PS}

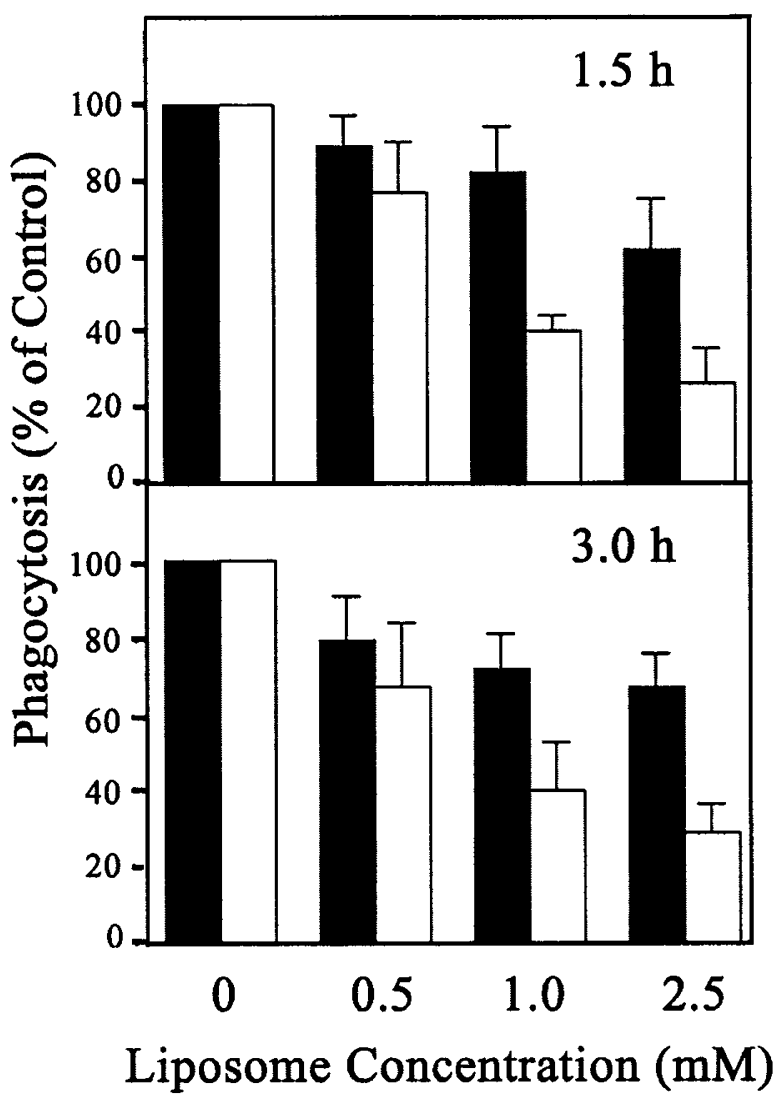

Figure 4 PS-containing liposomes inhibit the phagocytosis of apoptotic BL cells. (A) BL cells were treated with $200 \mu \mathrm{g} / \mathrm{ml}$ of etoposide for $1.5 \mathrm{~h}$ or $3.0 \mathrm{~h}$. Human monocyte derived macrophages were pretreated for $15 \mathrm{~min}$ at $37^{\circ} \mathrm{C}$ with various concentrations of liposomes containing either PS or PG. Liposomes were added to macrophages for $15 \mathrm{~min}$, prior to the addition of $\mathrm{BL}$ cells. Liposomes were present throughout the phagocytosis assay. The fold increase in phagocytosis of treated cells compared to control healthy cells was calculated. The effect of liposomes on phagocytosis is shown as the percentage of control phagocytosis of apoptotic cells. Error bars denote the standard deviation 
others and is most likely due to the existence of other molecules that facilitate this process. ${ }^{8,11,34}$ These results are consistent with numerous reports which demonstrate that PS-containing liposomes specifically inhibit phagocytosis of apoptotic cells. ${ }^{11,21}$ The ability of annexin $V$ to inhibit phagocytosis has also been used to demonstrate that PS mediates phagocytosis of apoptotic cells. ${ }^{35}$ In preliminary experiments we have found that annexin $V$ inhibited the phagocytosis of apoptotic BL cells by approximately $45 \%$ (data not shown).

\section{The $\mathrm{H}_{2} \mathrm{O}_{2}$-sensitve factor required for recognition of apoptotic cells is not PS}

The ability of $\mathrm{H}_{2} \mathrm{O}_{2}$ to inhibit phagocytosis of PS-expressing apoptotic cells suggested that an essential surface molecule(s) necessary for phagocytosis is sensitive to oxidization. To further examine this possibility, BL cells were treated with etoposide for $4 \mathrm{~h}$ to allow for PS translocation. These cells were phagocytosed at a high rate by macrophages (Figure $5 A)$. Co-treatment with $\mathrm{H}_{2} \mathrm{O}_{2}$ for the entire $4 \mathrm{~h}$ incubation

\section{A}
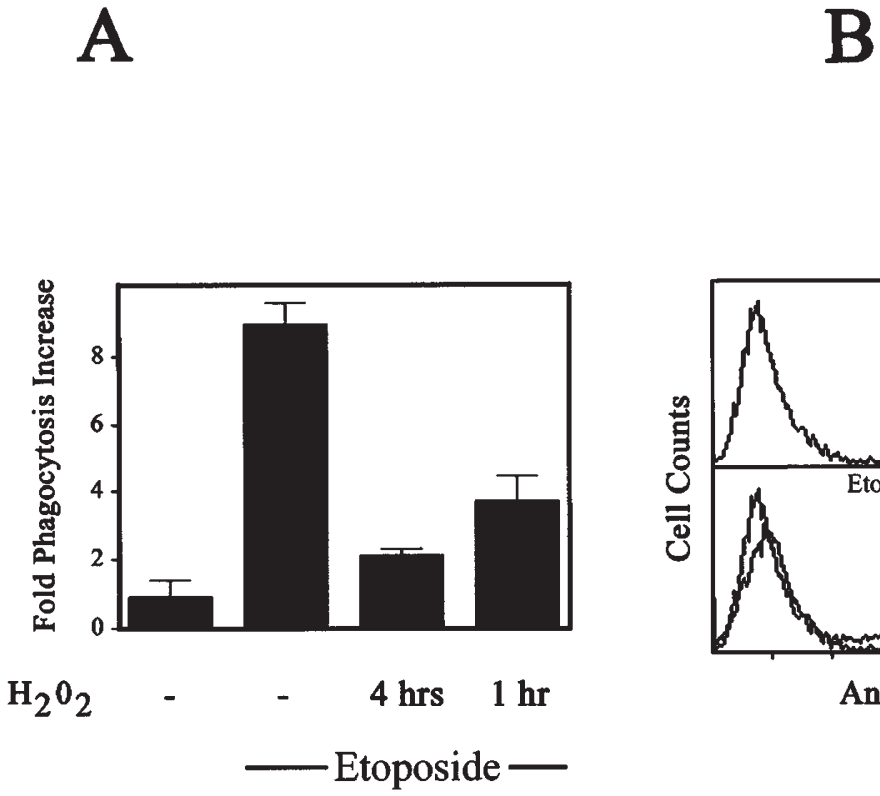

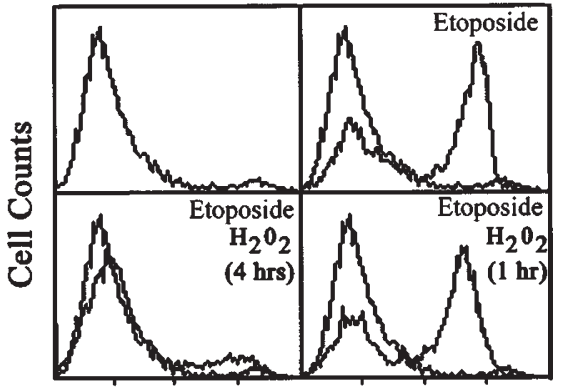

Annexin V- FITC

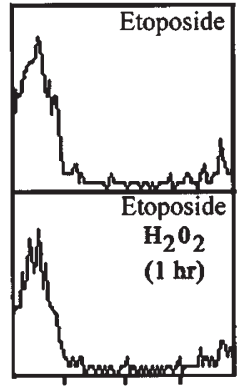

Propidium Iodide
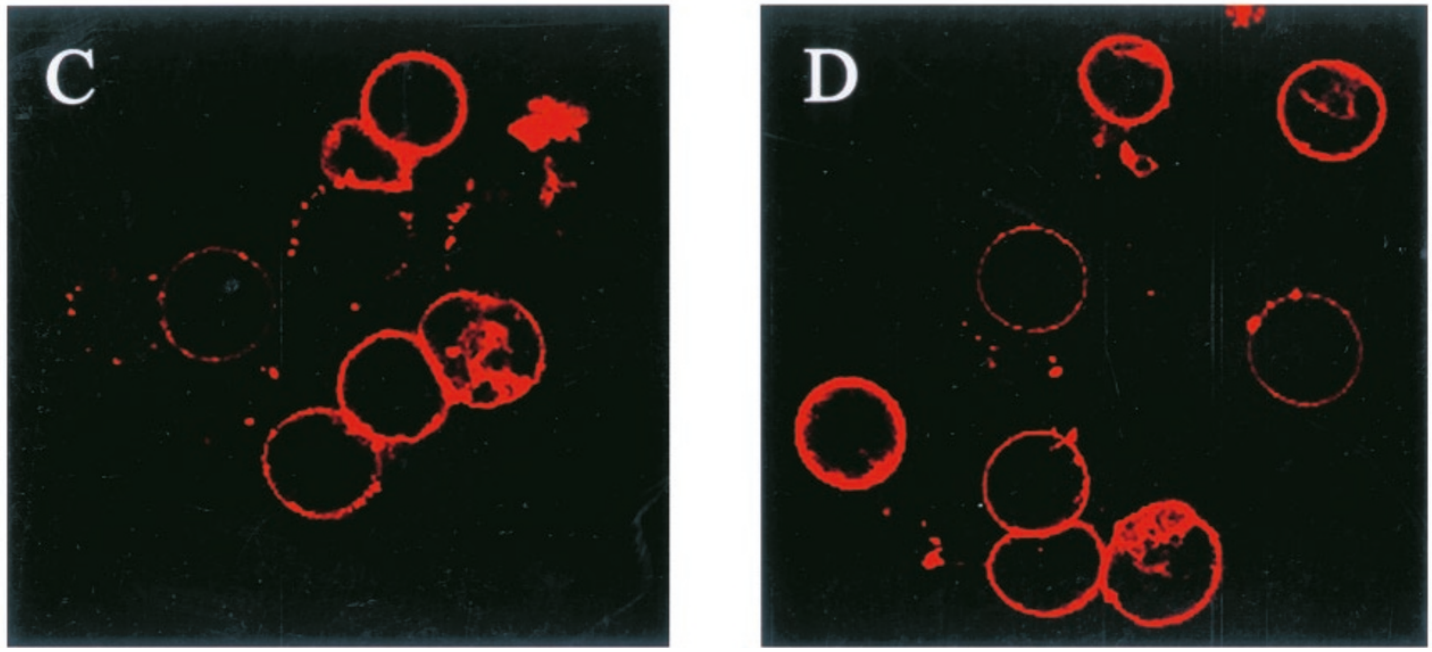

Figure $5 \quad \mathrm{H}_{2} \mathrm{O}_{2}$ treatment of etoposide-treated $\mathrm{BL}$ cells reduces phagocytosis but does not affect the binding of annexin $\mathrm{V}$ to cells. (A) BL cells were treated for $4 \mathrm{~h}$ in the absence or presence of etoposide $(200 \mu \mathrm{g} / \mathrm{ml})$ to induce PS externalization. Cells were also exposed to $200 \mu \mathrm{M} \mathrm{H}_{2} \mathrm{O}_{2}$ for either the last hour of etoposide treatment or for the entire $4 \mathrm{~h}$ incubation. (B) Cells were treated as indicated in $\mathbf{A}$ and stained with annexin $\mathrm{V}$ or propidium iodide. Note that cells treated with etoposide in the presence of $\mathrm{H}_{2} \mathrm{O}_{2}$ for the entire $4 \mathrm{~h}$ incubation are PS-negative while the cells treated with etoposide for $3 \mathrm{~h}$ followed by treatment with $\mathrm{H}_{2} \mathrm{O}_{2}$ for $1 \mathrm{~h}$ are PS positive. Error bars denote the standard deviation. (C) Confocal image of cells stained with annexin V-Alexa Fluor 595 after treatment with etoposide for $4 \mathrm{~h}$. (D) Confocal image of cells stained with annexin V-Alexa Fluor after treatment with $200 \mu \mathrm{M} \mathrm{H}_{2} \mathrm{O}_{2}$ during the last hour of etoposide treatment 
period inhibited phagocytosis by $90 \%$. However, as shown in Figure $5 \mathrm{~A}$, when $\mathrm{BL}$ cells were treated with etoposide for $3 \mathrm{~h}$ to induce PS externalization, and then exposed to $\mathrm{H}_{2} \mathrm{O}_{2}$ for $1 \mathrm{~h}$ to oxidize surface molecules, phagocytosis of these cells was still inhibited by $70 \%$. FACscan analysis indicated that these two populations of cells expressed identical levels of PS and that the cells maintained their membrane integrity since they were impermeable to propidium iodide (Figure 5B). These results suggest that the expression of PS does not guarantee efficient phagocytosis of apoptotic cells, and suggests that another factor(s) is required for recognition of apoptotic cells by macrophages.

Since it has been suggested that PS may be sensitive to oxidation during apoptosis ${ }^{36}$ we considered the possibility that PS may become damaged following $\mathrm{H}_{2} \mathrm{O}_{2}$-treatment and that this may account for the inability of macrophages to phagocytose apoptotic cells treated with $\mathrm{H}_{2} \mathrm{O}_{2}$. This is unlikely since serine moieties are relatively resistant to oxidative modification by $\mathrm{H}_{2} \mathrm{O}_{2}$, requiring $10-100 \mathrm{mM}$ concentrations and the presence of transition metals such as $\mathrm{Fe}^{2+}$ to undergo $\mathrm{H}_{2} \mathrm{O}_{2}$-induced damage. ${ }^{37,38}$ Our studies are carried out with $0.1-0.2 \mathrm{mM} \mathrm{H}_{2} \mathrm{O}_{2}$. As there are no published methods to measure selective oxidative modification of PS in the cell membrane, we performed two indirect experiments to address the possibility that $\mathrm{H}_{2} \mathrm{O}_{2}$ treatment may affect the functionality of PS. First, we evaluated the effect of $\mathrm{H}_{2} \mathrm{O}_{2}$-treatment on the binding of annexin $\mathrm{V}$ to apoptotic cells. FACscan analysis indicated that $\mathrm{H}_{2} \mathrm{O}_{2}$ treatment of cells does not affect the amount of annexin $\mathrm{V}$ that binds to apoptotic cells (Figures $1 \mathrm{~A}$ and $5 \mathrm{~B}$ ). However, the possibility exists that oxidation affects PS distribution on the plasma membrane. To address this possibility, etoposide-treated $\mathrm{BL}$ cells were exposed to $\mathrm{H}_{2} \mathrm{O}_{2}$ for $1 \mathrm{~h}$ and examined by confocal microscopy after staining with annexin V. As shown in Figure 5C, etoposide treated $\mathrm{BL}$ cells demonstrated punctuate, uniform, and patchy patterns when stained with annexin $\mathrm{V} . \mathrm{H}_{2} \mathrm{O}_{2}$ treated cells demonstrated identical annexin $\mathrm{V}$ staining patterns (Figure 5D). The results indicate that $\mathrm{H}_{2} \mathrm{O}_{2}$ treatment does not affect the amount of annexin $\mathrm{V}$ that binds PS and that $\mathrm{H}_{2} \mathrm{O}_{2}$ treatment does not affect the distribution of PS on the surface of apoptotic cells. Thus, if $\mathrm{H}_{2} \mathrm{O}_{2}$ were to modify PS it does not appear to affect the ability of PS to bind annexin V.

The second approach we took to examine whether $\mathrm{H}_{2} \mathrm{O}_{2}$ affects PS functionally was to treat PS with $\mathrm{H}_{2} \mathrm{O}_{2}$ and evaluate its ability to mediate phagocytosis of control (nonapoptotic) cells. It has been reported that PS can be incorporated into or onto the outer leaflet of the plasma membrane by mixing PS containing liposomes with healthy cells and that this leads to increased phagocytosis. ${ }^{25} \mathrm{We}$ treated PS liposomes with $\mathrm{H}_{2} \mathrm{O}_{2}$ for 30 min followed by removal of residual $\mathrm{H}_{2} \mathrm{O}_{2}$ with catalase. As shown in Figure $6 \mathrm{~A}$, when healthy $\mathrm{BL}$ cells were treated with PS-containing liposomes, $89 \%$ of the cells stained positive with annexin V, indicating that PS had been incorporated onto the plasma membrane. PS liposomes treated with $\mathrm{H}_{2} \mathrm{O}_{2}$ were incorporated onto the plasma membrane of healthy cells to a comparable degree. Note that this $\mathrm{H}_{2} \mathrm{O}_{2}$-treated PS is still recognizable by annexin $\mathrm{V}$. As shown in Figure 6B, there
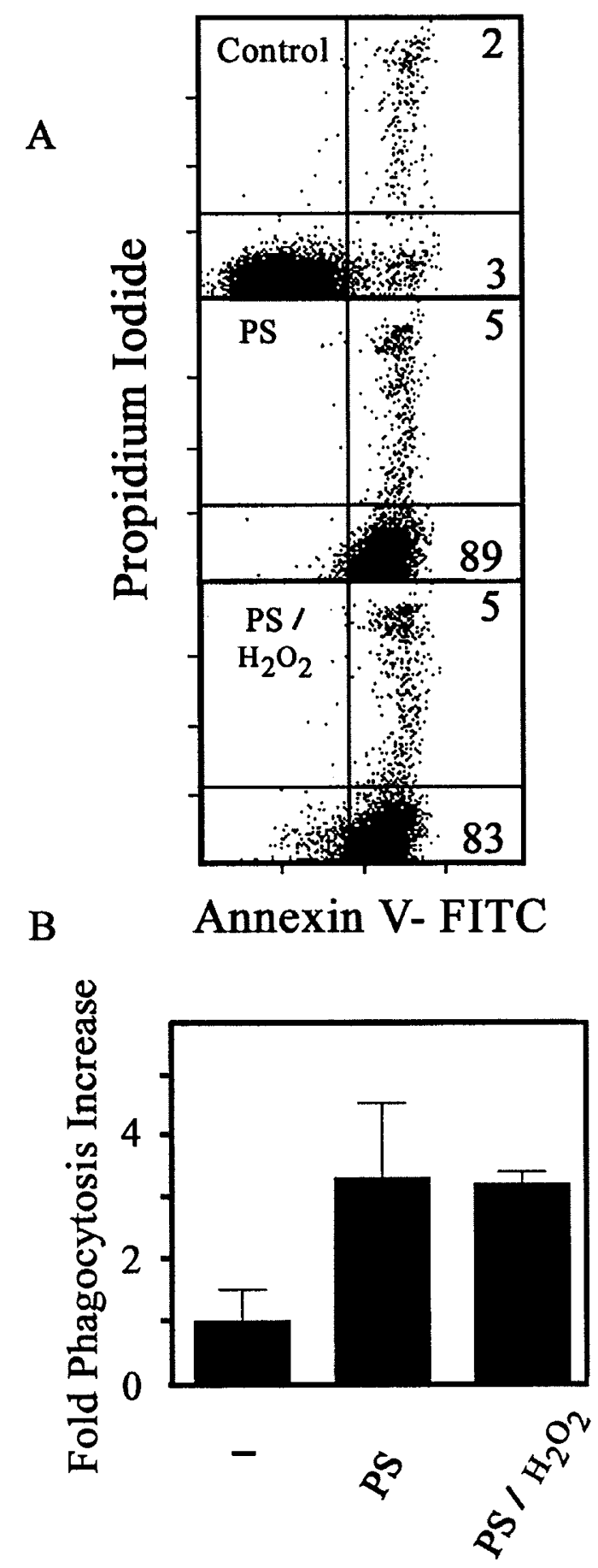

Figure 6 Phagocytosis of healthy BL cells following incorporation of PS from PS-containing liposomes onto the plasma membrane; absence of an effect of $\mathrm{H}_{2} \mathrm{O}_{2}$. PS-containing liposomes were incubated with or without $200 \mu \mathrm{M} \mathrm{H}_{2} \mathrm{O}_{2}$ for $30 \mathrm{~min}$, and the residual $\mathrm{H}_{2} \mathrm{O}_{2}$ was removed by treatment with 25 units of catalase for $30 \mathrm{~min}$. The liposomes were then incubated with BL cells to allow for the incorporation of PS onto the plasma membrane. (A) FACScan analysis was conducted using annexin V-FITC and PI staining of cells to monitor for membrane integrity and incorporation of PS onto the plasma membrane. (B) Healthy BL cells containing surface PS derived from PS-liposomes (with or without prior $\mathrm{H}_{2} \mathrm{O}_{2}$ treatment) were incubated with human macrophages in the absence of serum as described in Figure 2. Error bars denote the standard deviation 
was a threefold increase in the phagocytosis of healthy BL cells following incubation with PS-containing liposomes regardless of whether the liposomes had been treated with $\mathrm{H}_{2} \mathrm{O}_{2}$. These results indicate that the ability of $\mathrm{H}_{2} \mathrm{O}_{2}$ to inhibit phagocytosis of PS-expressing cells cannot be attributed to oxidative modification of PS on the cell surface since PS treated with $\mathrm{H}_{2} \mathrm{O}_{2}$ still maintains its functionality in terms of binding to proteins such as annexin $\mathrm{V}$ and promoting phagocytosis by macrophages.

\section{Cells induced to undergo apoptosis by $\mathrm{H}_{2} \mathrm{O}_{2}$ treatment are inefficiently phagocytosesd}

$\mathrm{H}_{2} \mathrm{O}_{2}$ treatment of $\mathrm{BL}$ cells inhibits apoptosis. In other cell types, however, exposure to oxidative stress has been reported to activate apoptosis. These cell types which include Jurkat $\mathrm{T}$ cells ${ }^{39}$ and murine thymocytes, ${ }^{40}$ may have protective mechanisms that ensure that adequate levels of ATP are maintained for apoptosis. To determine how well cells induced to undergo apoptosis in response to oxidative stress are phagocytosed, Jurkat $\mathrm{T}$ cells and murine thymocytes were exposed to either $\mathrm{H}_{2} \mathrm{O}_{2}$ for $6 \mathrm{~h}$ or to etoposide for $3 \mathrm{~h}$. Apoptosis was quantified by measuring PS externalization. As shown in Figure 7A, Jurkat T cells and murine thymocytes translocated similar levels of PS to the cell surface in response to $\mathrm{H}_{2} \mathrm{O}_{2}$ or etoposide treatments and approximately $30 \%$ of the cells stained positive with annexin V. Morphological analysis indicated that a similar proportion of cells had condensed nuclei, consistent with these cells dying by apoptosis (data not shown). Cell membrane integrity was unaffected by these treatments since cells remained impermeable to propidium iodide. Interestingly, phagocytosis of cells that had undergone apoptosis in response to $\mathrm{H}_{2} \mathrm{O}_{2}$ was only half that observed for cells undergoing apoptosis in response to etoposide. Higher concentrations of $\mathrm{H}_{2} \mathrm{O}_{2}$ did not inhibit phagocytosis by any greater degree. This may be due to incomplete oxidation of putative recognition factor(s) at the concentrations of $\mathrm{H}_{2} \mathrm{O}_{2}(20-100 \mu \mathrm{M})$ used to induce only apoptosis. Unfortunately, at higher concentrations of $\mathrm{H}_{2} \mathrm{O}_{2}$ $(200-400 \mu \mathrm{M})$, Jurkat and thymocyte membrane integrity is lost and cell death occurs by necrosis. Phagocytosis of necrotic cells is not sensitive to oxidation, and it is very difficult to inhibit phagocytosis of these cells with PS-containing liposomes (data not shown). Nonetheless, these results indicate that phagocytosis of cells induced to undergo apoptosis by $\mathrm{H}_{2} \mathrm{O}_{2}$ is relatively inefficient even though the cells express PS on the cell surface.

\section{Discussion}

The main physiological difference between apoptotic and necrotic death is thought to reside in how the cells affect the surrounding tissue. Apoptotic cell death results in cells that are efficiently removed by macrophages before membrane integrity is lost, and stimulates macrophages to secrete antiinflammatory cytokines. ${ }^{2,41}$ In contrast, the leakage of intracellular factors associated with necrosis serves as a potent natural adjuvant ${ }^{3,42}$ which can stimulate inflammatory responses as well as generate pathological immune responses to intracellular antigens. ${ }^{5}$
$\mathrm{H}_{2} \mathrm{O}_{2}$ induces cell death and alters cell death pathways. $^{27}$ It is generated in high levels by activated phagocytes (neutrophils and macrophages) during the

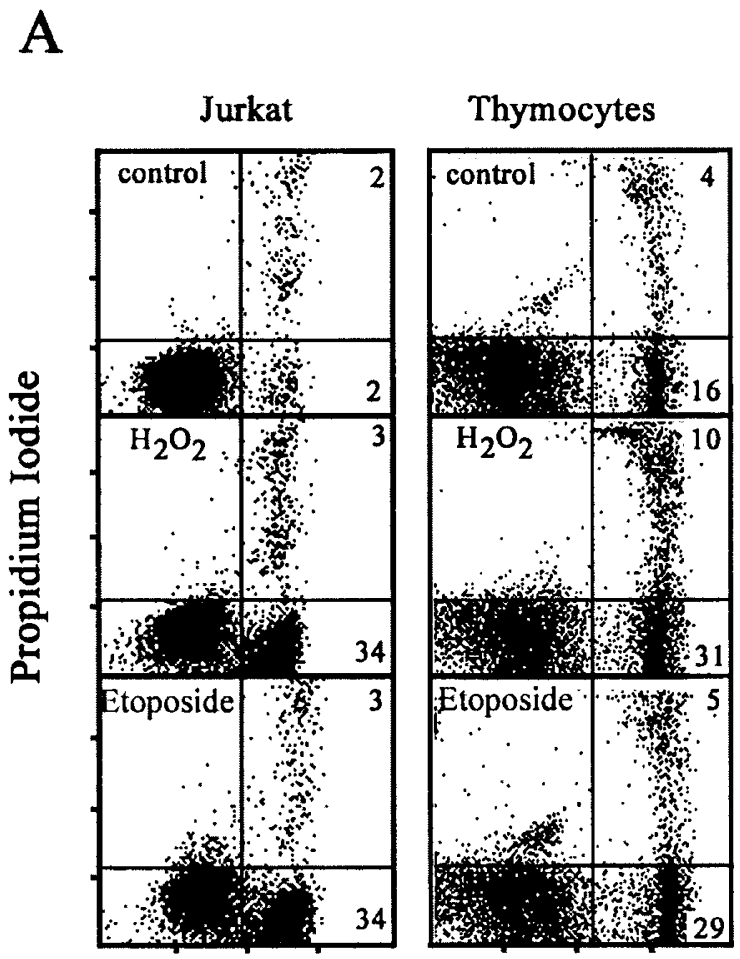

\section{Annexin V- FITC}

\section{B}
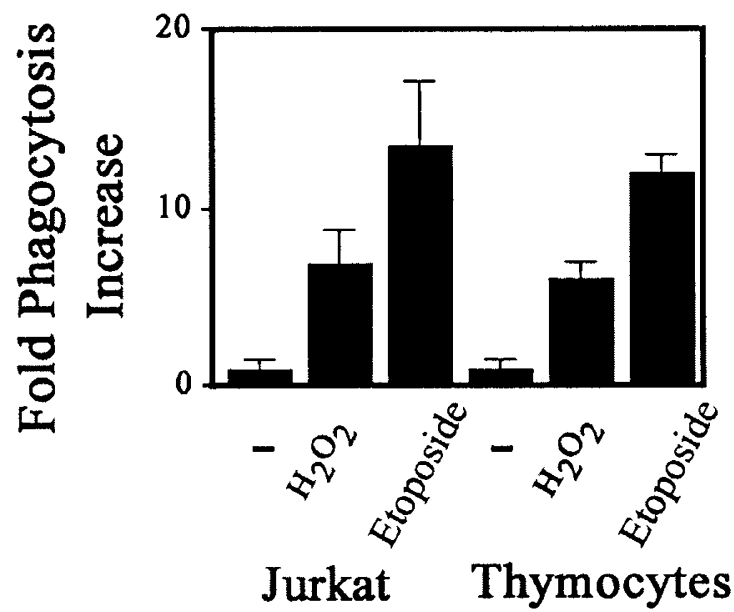

Figure 7 The phagocytosis of Jurkat T cells and murine thymocytes induced to undergo apoptosis with $\mathrm{H}_{2} \mathrm{O}_{2}$ is inefficient. Jurkat cells were treated with $100 \mu \mathrm{M} \mathrm{H}_{2} \mathrm{O}_{2}(6 \mathrm{~h})$ or $200 \mu \mathrm{g} / \mathrm{ml}$ VP16 (3h). Murine thymocytes were treated with $20 \mu \mathrm{M} \mathrm{H}_{2} \mathrm{O}_{2}(6 \mathrm{~h})$ or $50 \mu \mathrm{g} / \mathrm{ml}$ VP $16(3 \mathrm{~h})$. (A) PS externalization and cell viability were measured by two color FACScan analysis. (B) Phagocytosis of Jurkat cells or thymocytes was measured as described in the legend to Figure 2. Error bars denote the standard deviation 
inflammatory response to bacterial pathogens and tumor cells. $\mathrm{H}_{2} \mathrm{O}_{2}$ rapidly diffuses across cellular membranes to oxidize proteins, DNA, and lipids. It is a key oxidant since it has a high diffusion potential and can serve as a precursor for the more damaging reactive oxygen intermediates, including $\mathrm{OH}$. and $\mathrm{HOCl}$. $\mathrm{H}_{2} \mathrm{O}_{2}$ production by phagocytes is required for killing of tumor cells and pathogens, but can also cause damage to normal cells and tissues if not contained. (for review see; ${ }^{43,44}$ ).

Death induced by $\mathrm{H}_{2} \mathrm{O}_{2}$ can occur by a variety of mechanisms. Depending upon the target cell type and concentration, $\mathrm{H}_{2} \mathrm{O}_{2}$ can induce both apoptotic and necrotic forms of cell death. In many systems, the exposure of cells to low doses of $\mathrm{H}_{2} \mathrm{O}_{2}$ induces apoptosis, ${ }^{45}$ while higher concentrations of $\mathrm{H}_{2} \mathrm{O}_{2}$ cause necrotic forms of cell death. ${ }^{27,46}$ Since cells dying by necrosis are not phagocytosed until membrane integrity is lost, ${ }^{30}$ these cells function as potential inducers of inflammatory responses.

The timely removal of apoptotic cells by macrophages is dependent on the externalization of PS to the outer plasma membrane leaflet. ${ }^{1}$ Interestingly, the externalization of PS has been shown to be a change that occurs very early when apoptosis is induced. ${ }^{22}$ Consistent with a role for PS in the phagocytosis of apoptotic cells, we found that the phagocytosis of apoptotic BL cells coincides with the appearance of PS on the cell surface and is specifically inhibited by PS containing liposomes. In addition, when treated with etoposide together with $\mathrm{H}_{2} \mathrm{O}_{2}$, BL cells rapidly lose their ATP stores due to activation of PARP. ${ }^{27}$ These cells do not externalize PS and are poorly phagocytosed my macrophages. Thus, PS externalization correlates with the ability of macrophages to phagocytose BL cells. These results are consistent with published reports that the externalization of PS requires ATP $^{26}$ and is necessary for the phagocytosis of apoptotic cells. ${ }^{21}$

The novel observation that we report in this study is that cells induced to undergo apoptosis in the presence of $\mathrm{H}_{2} \mathrm{O}_{2}$ are not efficiently phagocytosed even though they have externalized PS. These results have two implications. First, apoptosis induced in vivo by oxidative stress may be accompanied by inefficient phagocytosis, which may contribute to perpetuation of inflammatory responses. Oxidative stress is associated with pathogen infection, ischemia-reperfusion injury (i.e. myocardial infarction and stroke), emphysema, acute respiratory distress syndrome, atherosclerosis, rheumatoid arthritis, and cancer (for review see $\left.;^{43}\right)$. The inefficient phagocytosis of apoptotic cells may contribute to the inflammation associated with these conditions. Second, our results raise the possibility that at least one more factor on the surface of apoptotic cells, in addition to $\mathrm{PS}$, is required to facilitate the efficient phagocytosis of the cells. This putative factor is sensitive to oxidative stress.

In addition to PS externalization, the opsonization of cells with complement, $8,16,18$ and integrin-mediated adhesion have been proposed to function as recognition signals that promote the phagocytosis of apoptotic cells. ${ }^{12}$ The possibility therefore exists that these putative mediators may be sensitive to oxidation. However, we have been unable to detect increased binding of complement subunits
C1q, C3, or C4, to etoposide-induced apoptotic BL cells, and have been unable to induce increased phagocytosis by the addition of these factors to the medium (unpublished results). In addition, RGD-containing peptides and integrinspecific antibodies did not inhibit phagocytosis of apoptotic $\mathrm{BL}$ cells (J Williams and E Shacter, unpublished observations). Therefore, we hypothesize that oxidative stress probably alters some other factor required for phagocytosis of apoptotic cells.

PS externalization is the only molecular change known to occur on the surface of apoptotic cells. Our results suggest that a factor, other than PS, that is sensitive to $\mathrm{H}_{2} \mathrm{O}_{2}$ treatment is required for the phagocytosis of apoptotic cells. This putative factor is either present on the surface constitutively or may be transported to the cell surface during apoptosis. It may function either in combination with PS or independently to provide a phagocytosis recognition signal. An alternative model consistent with our data is that oxidative stress induced by $\mathrm{H}_{2} \mathrm{O}_{2}$-treatment may alter apoptotic cells in other ways to diminish their phagocytosis. For example, $\mathrm{H}_{2} \mathrm{O}_{2}$-treatment could cause apoptotic cells to release factors or increase expression of factors that inhibit phagocytosis. Our study shows that a closer analysis of the apoptotic cell surface is merited to identify molecules sensitive to oxidation that function as macrophage recognition signals for phagocytosis of apoptotic cells.

\section{Materials and Methods}

\section{Cell lines and culture conditions}

The human leukemic cell line Jurkat (clone E6-1, ATCC) and the human Burkitt's lymphoma cell line BL- $41^{30}$ were cultured in RPMl 1640 medium supplemented with $10 \%$ heat-inactivated FCS and $50 \mu \mathrm{M} 2-\mathrm{ME}$ at $37^{\circ} \mathrm{C}$ in $5 \% \mathrm{CO}_{2}$ in air. Thymocytes were prepared from two C57BL/6 mice by removing thymus organs and dislodging cells by gently meshing thymus tissue with a screen. Thymocytes were washed twice in culture medium. For treatment with chemicals, cells were cultured in medium with etoposide (VP16, Sigma, St. Louis, MO, USA) or $\mathrm{H}_{2} \mathrm{O}_{2}$ (Fisher, New Jersey, USA) at concentrations indicated in the figure legends. The 3-aminobenzamide (3-AB, Sigma) was used at a concentration of $1 \mathrm{mM}$.

\section{Phagocytosis assay and FACScan analyses}

Human monocytes were isolated from leukopaques by elutriation and cultured in 24-well plates for 4 to 7 days at approximately $0.5 \times 10^{6}$ cells/ well in media containing $100 \mathrm{ng} / \mathrm{ml} \mathrm{rhM}-\mathrm{CSF}$. For phagocytosis assays, target cells were labeled with $0.12 \mathrm{ng} / \mathrm{ml}$ of the green fluorescent dye CFDA (Molecular Probes \#C-1157; 5,6-carboxyfluorescein diacetate, succinimidyl ester, mixed ester) in PBS at $37^{\circ} \mathrm{C}$ for $20 \mathrm{~min}$. The intensity of green CFDA staining of the target cells did not diminish over the course of any of the incubations. ${ }^{30}$ Cells were washed one time with Hanks' Balanced Salt Solution and incubated with human macrophages in culture medium for $1 \mathrm{~h}$. The ratio of target cells to macrophages was 2:1 unless otherwise indicated. Macrophages were washed four times to remove BL cells and stained with PE-labeled anti-CD 11b and antiCD 14 (PharMingen) for $30 \mathrm{~min}$ at $4^{\circ} \mathrm{C}$. Macrophages were then detached from plates with $1 \%$ lidocaine (Sigma) in PBS containing $0.5 \%$ FCS. Two color FACScan analysis was used to determine the percentage of red fluorescent macrophages that had phagocytosed 
green fluorescent target cells. Phagocytosis of cells is expressed as the fold increase in the percentage of macrophages that contain apoptotic cells compared to the percentage of macrophages that engulfed untreated (healthy) cells. Typically between $5-10 \%$ of the macrophages contain target cells after incubation with control (untreated) BL41 cells. Results were verified by fluorescence microscopy as described previously ${ }^{30}$ and showed that there was very little binding of green BL cells to the outer surface of the macrophages. Hence cell staining of both the green and red in the FACscan represent macrophages that have engulfed the target cells.

To determine the percentage of cells expressing PS, cells were stained with $0.5 \mu \mathrm{g}$ of annexin V-FITC (PharMingen) and $0.1 \mathrm{mg} / \mathrm{m}$ propidium iodide in $140 \mathrm{mM} \mathrm{NaCl}, 2.5 \mathrm{mM} \mathrm{CaCl}_{2}, 10 \mathrm{mM}$ HEPES, $\mathrm{pH} 7.4$, for $15 \mathrm{~min}$ at room temperature. Cells were then analyzed by two color FACScan. In control experiments, the percentage of apoptosis and membrane integrity were confirmed by fluorescence microscopy using Hoechst 33342 and propidium iodide as described previously. ${ }^{27}$

\section{Preparation of liposomes}

1,2-dioleoyl-sn-glycero-3-[phospho-L-serine] (sodium salt), 1,2-dioleoyl-sn-glycero-3-[phospho-rac(1-glycerol)] (sodium salt), and 1,2dioleoyl-sn-glycero-3-phosphocholine were purchased from Avanti (Alabaster, AL, USA). Liposomes were prepared as described by others. ${ }^{11}$ Briefly, lipids were supplied in chloroform/methanol and were dried under nitrogen gas, resuspended in PBS, and sonicated with a Virtis sonicator. Sonication was performed on ice, $10-30 \mathrm{~s}$ pulses, at a $10 \%$ output level. Liposomes contained $50 \%$ (M/M) phosphitidylcholine, and either $50 \%(\mathrm{M} / \mathrm{M})$ phosphitidylserine or $50 \%(\mathrm{M} / \mathrm{M})$ phosphidylglycerol. Liposomes were used within $4 \mathrm{~h}$ of preparation.

\section{Assay for cellular ATP}

ATP content in cells was assayed as described previously, ${ }^{31}$ with the following modifications. BL cells $\left(0.5 \times 10^{6}\right)$ were pelleted and then lysed in $150 \mu \mathrm{l}$ of $3 \% \mathrm{HClO}_{4}$, followed by neutralization with $75 \mu \mathrm{l}$ of $1 \mathrm{M} \mathrm{KOH}$, and $30 \mu \mathrm{l}$ of potassium phosphate buffer $\left(1 \mathrm{M} \mathrm{K}_{2} \mathrm{HPO}_{4} /\right.$ $\mathrm{KH}_{2} \mathrm{PO}_{4}, \mathrm{pH}$ 7.4) for a 15 min incubation on ice. Cells were then pelleted by centrifugation at $9000 \times g$ for $2 \mathrm{~min}$. The supernatant was used to determine ATP content. Five $\mu$ l of sample was mixed with $45 \mu \mathrm{l}$ of potassium phosphate buffer containing $4 \mathrm{mM} \mathrm{MgSO}_{4}$, and added to a 96 well plate containing $50 \mu \mathrm{l}$ of $0.8 \mathrm{mg} / \mathrm{ml}$ luciferin (Sigma) in $50 \mathrm{mM} \mathrm{NaAsO}_{2}, 20 \mathrm{mM} \mathrm{MgSO}_{4}$. Chemiluminescence was determined with a luminometer. ATP was determined from a standard curve (linear range $20-800 \mathrm{nM}$ ). ATP levels in treated cells are expressed as a percentage of the ATP levels in control cells.

\section{Confocal microscopy}

$1 \times 10^{6}$ apoptotic BL cells were stained with $1 \mu \mathrm{l}$ annexin V-Alexa Fluor 595 (Molecular Probes, Eugene, Oregon, USA) in $20 \mu \mathrm{l}$ of $140 \mathrm{mM}$ $\mathrm{NaCl}, 2.5 \mathrm{mM} \mathrm{CaCl}_{2}, 10 \mathrm{mM}$ HEPES, $\mathrm{pH}$ 7.4. Approximately $5 \mu \mathrm{l}$ of a cell suspension was then added to a glass slide and mounted with a cover slip. Annexin V-Alexa Fluor 595 was visualized using a LSM5 PASCAL scanning confocal microscope (Carl Zeiss, Thornwood, NY, USA). Samples were visualized with a $40 \times$ objective and fluorescence was collected using 543-560 $\mathrm{nM}$ bandpass emission filters. Images represent a single optical section approximately $1.0 \mu \mathrm{m}$ in thickness.

\section{Acknowledgements}

We thank Valerie Calvert for providing the human monocytes and Jan Lee for assistance in generating murine thymocytes. We thank Yang-Ja Lee, Elizabeth Shores, and Giovanna Tosato for critical reading of the manuscript, and members of the Shacter laboratory for numerous helpful discussions. This article is a United States Government Work paper as defined by the US Copyright Act.

\section{References}

1. Savill J and Fadok V (2000) Corpse clearance defines the meaning of cell death. Nature 407: 784-788

2. Voll RE, Hermann M, Roth EA, Stach C, Kalden JR and Girkontaite I (1997) Immunosuppressive effects of apoptotic cells. Nature 390: 350-351

3. Sauter B, Albert ML, Francisco L, Larsson M, Somersan S. and Bhardwaj N. (2000) Consequences of cell death: exposure to necrotic tumor cells, but not primary tissue cells or apoptotic cells, induces the maturation of immunostimulatory dendritic cells. J. Exp. Med. 191: 423-434

4. Botto M, Dell'Agnola C, Bygrave AE, Thompson EM, Cook HT, Petry F, Loos M, Pandolfi PP and Walport MJ (1998) Homozygous C1q deficiency causes glomerulonephritis associated with multiple apoptotic bodies. Nat. Genet. 19: 56-59

5. Herrmann M, Voll RE and Kalden JR (2000) Etiopathogenesis of systemic lupus erythematosus. Immunol. Today 21: $424-426$

6. Scott RS, McMahon EJ, Pop SM, Reap EA, Caricchio R, Cohen PL, Earp HS and Matsushima GK (2001) Phagocytosis and clearance of apoptotic cells is mediated by MER. Nature 411: 207-211

7. Devitt A, Moffat OD, Raykundalia C, Capra JD, Simmons DL and Gregory CD (1998) Human CD14 mediates recognition and phagocytosis of apoptotic cells. Nature 392: 505-509

8. Ogden CA, deCathelineau A, Hoffmann PR, Bratton D, GhebrehiwetB, Fadok VA and Henson PM (2001) C1q and mannose binding lectin engagement of cell surface calreticulin and cd91 initiates macropinocytosis and uptake of apoptotic cells. J. Exp. Med. 194: 781-796

9. PlattN, SuzukiH, Kurihara Y, Kodama Tand Gordon S (1996) Role for the class A macrophage scavenger receptor in the phagocytosis of apoptotic thymocytes in vitro. Proc. Natl. Acad. Sci. USA 93: 12456-12460

10. Bird DA, Gillotte KL, Horkko S, Friedman P, Dennis EA, Witztum JL and Steinberg D (1999) Receptors for oxidized low-density lipoprotein on elicited mouse peritoneal macrophages can recognize both the modified lipid moieties and the modified protein moieties: implications with respect to macrophage recognition of apoptotic cells. Proc. Natl. Acad. Sci. USA 96: 6347-6352

11. Fadok VA, Bratton DL, Rose DM, Pearson A, Ezekewitz RA and Henson PM (2000) A receptor for phosphatidylserine-specific clearance of apoptotic cells. Nature 405: 85-90

12. Savill J, Dransfield I, Hogg N and Haslett C (1990) Vitronectin receptor-mediated phagocytosis of cells undergoing apoptosis. Nature 343: 170-173

13. Finnemann SC and Rodriguez-Boulan E (1999) Macrophage and retinal pigment epithelium phagocytosis: apoptotic cells and photoreceptors compete for alphavbeta3 and alphavbeta5 integrins, and protein kinase $C$ regulates alphavbeta5 binding and cytoskeletal linkage. J. Exp. Med. 190: 861-874

14. Moffatt OD, Devitt A, Bell ED, Simmons DL and Gregory CD (1999) Macrophage recognition of ICAM-3 on apoptotic leukocytes. J. Immunol. 162: 6800-6810

15. Albert ML, Kim JI and Birge RB (2000) Alphavbeta5 intregrin recruits the crkllDock180-rac1 complex for phagocytosis of apoptotic cells. Nat. Cell Biol. 2: 899-905

16. Mevorach D, Mascarenhas JO, Gershov D and Elkon KB (1998) Complementdependent clearance of apoptotic cells by human macrophages. J. Exp. Med. 188: $2313-2320$

17. Gershov D, Kim S, Brot N and Elkon KB (2000) C-Reactive protein binds to apoptotic cells, protects the cells from assembly of the terminal complement components, and sustains an antiinflammatory innate immune response: implications for systemic autoimmunity. J. Exp. Med. 192: 1353-1364 
18. Taylor PR, Carugati A, Fadok VA, Cook HT, Andrews M, Carroll MC, Savill JS, Henson PM, Botto M and Walport MJ (2000) A hierarchical role for classical pathway complement proteins in the clearance of apoptotic cells in vivo. J. Exp. Med. 192: $359-366$

19. Savill J, Hogg N, Ren Y and Haslett C (1992) Thrombospondin cooperates with CD36 and the vitronectin receptor in macrophage recognition of neutrophils undergoing apoptosis. J. Clin. Invest. 90: 1513-1522

20. Balasubramanian K, Chandra J and Schroit AJ (1997) Immune clearance of phosphatidylserine-expressing cells by phagocytes. The role of beta2glycoprotein I in macrophage recognition. J. Biol. Chem. 272: 31113-31117

21. Fadok VA, Voelker DR, Campbell PA, Cohen JJ, Bratton DL and Henson PM (1992) Exposure of phosphatidylserine on the surface of apoptotic lymphocytes triggers specific recognition and removal by macrophages. J. Immunol. 148: 2207-2216

22. Verhoven B, Schlegel RA and Williamson P (1995) Mechanisms of phosphatidylserine exposure, a phagocyte recognition signal, on apoptotic $T$ lymphocytes. J. Exp. Med. 182: 1597-1601

23. Martin SJ, Reutelingsperger CP, McGahon AJ, RaderJA, van Schie RC, LaFace DM and Green DR (1995) Early redistribution of plasma membrane phosphatidylserine is a general feature of apoptosis regardless of the initiating stimulus: inhibition by overexpressing of Bcl-2 and Abl. J. Exp. Med. 182: 15451556

24. Fadok VA, Bratton DL, Frasch SC, Warner ML and Henson PM (1998) The role of phosphatidylserine in recognition of apoptotic cells by phagocytes. Cell Death Differ. 5: 551-562

25. Fadok VA, de Cathelineau A, Daleke DL, Henson PM and Bratton DL (2001) Loss of phospholipid asymmetry and surface exposure of phosphatidylserine is required for phagocytosis of apoptotic cells by macrophages and fibroblasts. J. Biol. Chem. 276: 1071-1077

26. Leist M, Single B, Castoldi AF, Kuhnle S and Nicotera P (1997) Intracellular adenosine triphosphate (ATP) concentration: a switch in the decision between apoptosis and necrosis. J. Exp. Med. 185: 1481-1486

27. Lee YJ and Shacter E (1999) Oxidative stress inhibits apoptosis in human lymphoma cells. J. Biol. Chem. 274: 19792-19798

28. Schraufstatter IU, Hinshaw DB, Hyslop PA, Spragg RG and Cochrane CG (1986) Oxidant injury of cells. DNA strand-breaks activate polyadenosine diphosphateribose polymerase and lead to depletion of nicotinamide adenine dinucleotide. J. Clin. Invest. 77: 1312-1320

29. Hyslop PA, Hinshaw DB, Halsey Jr WA, Schraufstatter IU, Sauerheber RD, Spragg RG, Jackson JH and Cochrane CG (1988) Mechanisms of oxidantmediated cell injury. The glycolytic and mitochondrial pathways of ADP phosphorylation are major intracellular targets inactivated by hydrogen peroxide. J. Biol. Chem. 263: 1665-1675

30. Shacter E, Williams JA, Hinson RM, Senturker S and Lee YJ (2000) Oxidative stress interferes with cancer chemotherapy: inhibition of lymphoma cell apoptosis and phagocytosis. Blood 96: 307-313
31. Lee YJ and Shacter $E(2000)$ Hydrogen peroxide inhibits activation, not activity, of cellular caspase-3 in vivo. Free Radic. Biol. Med. 29: 684-692

32. Eguchi Y, Shimizu S and Tsujimoto Y (1997) Intracellular ATP levels determine cell death fate by apoptosis or necrosis. Cancer Res. 57: 1835-1840

33. Savill JS, Henson PM and Haslett C (1989) Phagocytosis of aged human neutrophils by macrophages is mediated by a novel 'charge-sensitive' recognition mechanism. J. Clin. Invest. 84: 1518-1527

34. Fadok VA, Warner ML, Bratton DL and Henson PM (1998) CD36 is required for phagocytosis of apoptotic cells by human macrophages that use either a phosphatidylserine receptor or the vitronectin receptor (alpha $v$ beta 3 ). J. Immunol. 161: 6250-6257

35. Krahling S, Callahan MK, Williamson P and Schlegel RA (1999) Exposure of phosphatidylserine is a general feature in the phagocytosis of apoptotic lymphocytes by macrophages. Cell Death Differ. 6: 183-189

36. Kagan VE, Fabisiak JP, Shvedova AA, Tyurina YY, Tyurin VA, Schor NF and Kawai K (2000) Oxidative signaling pathway for externalization of plasma membrane phosphatidylserine during apoptosis. FEBS Lett. 477: 1-7

37. Shacter $E(2000)$ Quantification and significance of protein oxidation in biological samples. Drug Metab. Rev. 32: 307-326

38. Berlett BS and Stadtman ER (1997) Protein oxidation in aging, disease, and oxidative stress. J. Biol. Chem. 272: 20313-20316

39. Dumont A, Hehner SP, Hofmann TG, Ueffing M, Droge Wand Schmitz ML (1999) Hydrogen peroxide-induced apoptosis is CD95-independent, requires the release of mitochondria-derived reactive oxygen species and the activation of NF-kappaB. Oncogene 18: 747-757

40. Virag L, Scott GS, Cuzzocrea S, Marmer D and Salzman AL (1998) Peroxynitriteinduced thymocyte apoptosis: the role of caspases and poly (ADP-ribose) synthetase (PARS) activation. Immunology 94: $345-355$

41. Fadok VA et al (1998) Macrophages that have ingested apoptotic cells in vitro inhibit proinflammatory cytokine production through autocrine/paracrine mechanisms involving TGF-beta, PGE2, and PAF. J. Clin. Invest. 101:890-898

42. Gallucci S, Lolkema M and Matzinger P (1999) Natural adjuvants: endogenous activators of dendritic cells. Nat. Med. 5: 1249-1255

43. Babior BM (2000) Phagocytes and oxidative stress. Am. J. Med. 109: 33-44

44. ShacterEand Weitzman SA (2002) Chronic Inflammation and Cancer. Oncology 17: $217-226$

45. Buttke TM and Sandstrom PA (1994) Oxidative stress as a mediator of apoptosis Immunol. Today 15: 7-10

46. Lennon SV, Martin SJ and Cotter TG (1991) Dose-dependent induction of apoptosis in human tumour cell lines by widely diverging stimuli. Cell Prolif. 24: $203-214$ 